\title{
Introduction to the Research Handbook on Foreign Direct Investment
}

\author{
Markus Krajewski and Rhea Tamara Hoffmann
}

Foreign Direct Investment (FDI) is a key driver of international economic integration. While FDI has always been of significant importance for the growth and development of national economies, its tremendous global relevance is a more recent phenomenon as seen by the enormous rise of FDI since the 1990s. ${ }^{1}$ This broad trend is based on various economic, political and legal transformations. The liberalisation of capital markets and the abolishment of foreign exchange restrictions as a result of neoliberal economic policies in many Western countries in the 1980s as well as the transformation of centrally planned economies into liberal market systems in many Eastern European and former Soviet countries led to a sharp increase of opportunities for transnational commercial activities. In addition, many developing countries changed their national development policies - often under pressure from international financial institutions or due to severe foreign debt burdens - from inward-looking industrialisation strategies to outward-oriented trade and investment approaches. Economic and political reforms increased the potential for large merger and acquisition transactions leading to a growth of multinational enterprises. Finally, countries liberalised their domestic legal systems by reducing barriers and restrictions in private commercial activities.

In light of these recent developments it should not be surprising that the law governing FDI only entered centre-stage of the international legal discourse two decades ago. While the first international investment agreements (IIAs) were signed as early as 1959, the international law of FDI did not feature prominently in international affairs until the late 1990s. The exponential increase in the number of IIAs signed by virtually all countries of the world and of the investment disputes adjudicated on the basis of these agreements since the 2000s led to a growing interest of legal scholars and practitioners in this field of law. Even though the number of newly signed IIAs is no longer growing as fast as ten years ago and FDI flows experienced a significant reduction in the 2007/2008 financial crisis, the relevance of international investment law remains unchallenged. FDI is governed by a complex and multi-level legal regime comprising of multilateral, regional and bilateral treaties - some specifically addressing foreign investment others covering investment as just one issue of many - as well as domestic legislation and contracts between states and investors. In addition, international non-binding standards contain responsibilities of investors which may affect investment decisions.

The body of FDI law underwent tremendous transformations in the past decades. In the 1970s and 1980s, investment law was shaped by development policies based on

1 On these developments see generally UNCTAD, World Investment Report 2017: Investment and the Digital Economy (2017). 


\section{Research handbook on foreign direct investment}

investment in large infrastructure and extractive industries projects. These projects were often regulated through investment contracts between the state and the respective foreign investor. While investment contracts remain important, international investment treaties have become the most significant sources of international investment law currently. This can be shown by the spectacular rise of the number of bilateral investment treaties (BITs) since the late 1980s. Between 1980 and 2017, 2,946 BITs have been signed. ${ }^{2}$ Equally, investor-state dispute settlement (ISDS) cases proliferated and are adjudicated by a variety of investment tribunals and other bodies. As of July 2018, there are 855 known treaty-based investor-state arbitrations. ${ }^{3}$ The diversity of the respective decisions, with often conflicting interpretations, also shows the wide discretion of arbitration tribunals when applying broad and general terms in investment treaties.

Following general global political trends, the legal regime was shaped by a neoliberal economic agenda since the early 1990s and accelerated by the end of the Cold War and the transition of many former centrally planned into market-based economies which prompted the respective countries to underline the commitments to liberal markets with the conclusion of investment agreements.

In light of the economic and financial crises which led to a partial delegitimisation of the most far-reaching neoliberal approaches, state interventions into the economy and the need for regulation re-entered the agenda. This also influenced international investment law as new BITs increasingly try to provide for more policy space.

Most recently, the impact of international investment law on the Sustainable Development Goals (SDGs) and human rights became an issue of political and academic interest. One reason for this relates to the fact that the lack of business obligations in international law stands in stark contrast to the rights of investors under international investment law. A recent initiative in the United Nations (UN) to develop a legally binding instrument ${ }^{4}$ for business obligations in the field of human rights aims at changing this. The UN Treaty process might also be used to push for the inclusion of investor obligations and remedies for victims of business abuses in reformed IIAs. Today, the vast majority of IIAs do not mention human rights. However, recently states have started to include human rights in their treaties and investment arbitration tribunals increasingly consider human rights issues.

Increasing international investment, the proliferation of IIAs, domestic legislation, and investor-state contracts have contributed to the development of a new field of international law that defines obligations between host states and foreign investors with ISDS involving not only vast sums but also a panoply of rights, duties and shifting objectives at the juncture of national and international law and policy.

2 UNCTAD, IIA Issues Note, Recent Developments in the International Investment Regime (May 2018) 2.

3 See UNCTAD, Investment Policy Hub, Investment Dispute Settlement Navigator, available at http://investmentpolicyhub.unctad.org/ISDS accessed 24 July 2018.

4 The Open-Ended Intergovernmental Working Group on Transnational Corporations and other Business Enterprises with Respect to Human Rights (OEIGWG) was established by the UN Human Rights Council in 2014. See Human Rights Council, Elaboration of an international legally binding instrument on transnational corporations and other business enterprises with respect to human rights, A/HRC/RES/26/9, 14 July 2014. 
In this Research Handbook, 28 leading legal scholars and junior scholars from six continents contributed original chapters on FDI from various perspectives with a strong academic focus on key areas of current research interest and future and upcoming issues or a research agenda. The chapters in the Research Handbook are arranged around the following five broad themes: I. Foundations; II. International Investment Agreements; III. Investment Regulation and Incentives; IV. Regional Perspectives; as well as V. Challenges and Contentious Issues.

\section{FOUNDATIONS}

The four chapters in this part deal with foundational issues of international investment covering economic, political economy and legal approaches. The first chapter 'The political economy of bilateral investment treaties' compiled by Sarah Bauerle Danzman offers a non-legal view on the much-debated economic effects of BITs. The chapter provides a synthetic and critical review of political economy research related to BITs and their effect on patterns of FDI flows. The analysis of political institutions and FDI is grounded in a framework that emphasises the sources and consequences of expropriation risk. Moreover, the chapter provides an overview of the broad but mostly inconclusive empirical literature that studies whether, how, and under what conditions BITs may influence investment flows. Amongst others, the chapter overviews attempts to answer empirically the question of why governments agree to BITs and their terms at all. Consequently, it considers the unintended consequences of BITs, particularly with respect to the increased use of investor-state arbitration, and whether these costs place undue constraints on host governments. Finally, the author suggests three emerging areas of research that future work on BITs, FDI and development outcomes should pursue. In contrast to this political economy perspective, the various 'Approaches to foreign direct investment in legal research' are systematically described by Stephan W Schill and Kerem Gülay. They provide an extensive overview of current and future research questions as well as theories and methods in international investment law. The analysis of legal aspects of FDI has led to a veritable boom in scholarship and the emergence of a separate legal discipline at the intersection of international and national, public and private law. Building on a broad understanding of legal approaches to FDI, the chapter provides an overview of the architecture of the legal regime governing FDI and argues that FDI regulation is best understood as a transnational legal order. Moreover, the chapter provides an overview of theoretical approaches to international investment law, methods of legal research and a typology of research questions.

The foundational part of the Research Handbook is enriched with a chapter on 'Foreign investment law and developing countries' by Antonius Rickson Hippolyte. His chapter seeks to highlight the importance of compliance with foreign investment law if developing countries wish to secure greater levels of FDI and enhance their participation in the global economy. The author examines developing countries' historical scepticism towards foreign investment law as well as the emergence of Third World approaches to international law. Notwithstanding critical views in developing countries, Hippolyte argues that developing countries should move beyond mere criticism of the 


\section{Research handbook on foreign direct investment}

BIT regime and aspire to negotiate more beneficial BITs with investor obligations to protect their interests. He illustrates that constructive participation in the foreign investment regime would prove more beneficial to developing countries than mere criticism, and the constant backlash against this system as tolerance of and compliance with foreign investment law is crucial to developing countries' future ability to attract FDI. A fourth chapter in the foundational part of the Research Handbook is compiled by Lise Johnson. Her chapter 'FDI, international investment agreements and the sustainable development goals' explores the interrelationship between foreign direct investment, IIAs and the SDGs on a foundational level. The SDGs are more and more used to inform the reform of international investment law in a way that FDI should aim at harnessing sustainable development. Therefore, the chapter first explains the basic concepts with a focus on positive and negative effects of FDI on sustainable development. The chapter examines those issues by focusing on the connections between FDI and certain SDGs. Therefore, the chapter provides a brief overview of the SDGs and offers a preliminary discussion of how IIAs might affect FDI's contributions to specific SDGs. After examining specific SDGs, the chapter offers some more general thoughts on how the scope of investment treaties reflect, and are relevant to, sustainable development.

\section{INTERNATIONAL INVESTMENT AGREEMENTS}

Today, there are more than 3,300 IIAs worldwide, including free trade agreements (FTAs) or economic partnership agreements with investment provisions. The last years have seen an expansion of negotiations of broad economic agreements. At the same time, the IIA regime is undergoing a period of reflection, review and reform. Therefore the first chapter by Elisabeth Tuerk, Jorun Baumgartner and Dafina Atanasova draws on 'Trends and reform debates' and gives insights into the current state of play of policy-making and reforms at the bilateral as well as regional or multilateral level. Growing unease with the current functioning of the global regime of IIAs, together with today's sustainable development imperative, the greater role of governments in the economy and the evolution of the investment landscape, have triggered a move towards reforming international investment rule-making to make it better suited to today's policy challenges. This chapter provides an overview of key points of criticism against the current IIA regime and recent trends and debates informing IIA reform. As such, it lays out selected IIA aspects and prepares the ground for more in-depth discussions by other authors in later chapters. Catharine Titi analyses the 'Scope of international investment agreements and substantive protection standards' building a key point of reference throughout the Research Handbook. The chapter discusses the scope of international investment treaties with an emphasis on the notion of 'investment' and 'investor' and the most important substantive standards these treaties grant foreign investors such as national treatment, protection against expropriation and fair and equitable treatment. Finally, the chapter studies the use of exceptions and exclusions in international investment treaties. The chapter identifies new trends and anticipates forthcoming changes, outlining a research agenda in a forward-looking manner. The main elements of 'Investment dispute settlement' as it stands, as well as possible 
reforms of investor-state arbitration, are described by Anna De Luca and Giorgio Sacerdoti. As of the 1960s the international law of foreign investment has been characterised by the emergence of international arbitration as the preferable means of settling investment disputes, and the increasing recognition by treaty law of private investors' ability to espouse therein their international claims directly against host states. The chapter provides a general overview of investment treaty arbitration and its features as well as International Centre for Settlement of Investment Disputes (ICSID) and non-ICSID arbitration more specifically. Furthermore, procedural issues, the award and the post-award procedure are explained. Finally, the chapter also looks at new approaches to investment dispute settlement such as the investment court system of the European Union (EU) or the proposal for a multilateral investment court. Last but not least, the interaction between trade and investment is discussed by Martín Molinuevo and Michael Jacobson with a focus on 'FDI and services trade: connections in rules and dispute settlement'. The contribution highlights current approaches in FTAs which cover both trade in services liberalisation and investment protection. In particular, the chapter reviews how disciplines on trade in services apply to FDI. It assesses the relationship between FDI and on trade in services and brings attention to potential legal conflicts between them. Finally, it considers potential implications of this relationship in dispute resolution by considering how investment disputes in services would be considered at the dispute settlement mechanism of the World Trade Organization (WTO) and vice versa.

\section{INVESTMENT REGULATIONS AND INCENTIVES}

Besides the growing number of IIAs, other rules covering foreign investment should not be overlooked. The first chapter in this part covers regulations other than IIAs, focusing on 'Investor-state contracts'. Ivar Alvik explores in this chapter the complex interaction between municipal law of the host state and international law with respect to investor-state contracts. The chapter first examines the legal, practical and theoretical aspects of how these contracts become subject to international law, both historically and today, especially through the medium of international arbitration. It then discusses the question of the applicable law, including the relationship between municipal law and international law. Furthermore, the chapter examines more closely the substantive international law applicable to investor-state contracts, which includes both rules protecting contracts as assets or legitimate expectations against illegitimate intrusions by state power. Finally, the crucial and difficult question of contractual restriction of state powers, and the more specific international legal approach that has developed in relation to so-called stabilisation clauses is explored. Additionally, Panayotis M Protopsaltis gives a detailed overview of 'Investment guarantees and political risk insurance' and shows that this field of research is relatively unexplored offering ample room for research, ranging from the structure of the market and the conditions of guarantee allocation and insurance subscription to the wider question of the role of investment guarantees and political risk insurance in the development of international investment law. The first part of his chapter explores the particular nature of political risk and the consequent benefits and difficulties involved in the allocation 


\section{Research handbook on foreign direct investment}

of guarantees and subscription of political risk insurance. Moreover, the chapter describes the investment guarantee and political risk insurance market, in particular, the public and private political risk insurance providers. Finally, the chapter focuses on the scope of investment guarantees, as exemplified by the restrictions introduced by the Multilateral Investment Guarantee Agency in relation to coverage and compensation for expropriation.

\section{REGIONAL PERSPECTIVES}

This part of the Research Handbook investigates FDI issues from regional perspectives covering all continents. Though all chapters in this part cover current research, state practice and reforms in domestic investment law and international investment law, each chapter also has a specific focus depending on contentious issues in the specific region. Dominic Npoanlari Dagbanja highlights not only the role of the search for development in 'Africa', but also the diversity and complexity of the legal regimes for FDI protection in Africa and the potential for conflict amongst them. The chapter contributes to an understanding of the nature and scope of international investment law in Africa and the role of development in the making of IIAs in Africa. The chapter argues that investment dispute settlement tribunals have an obligation to take account of the development objective in interpreting African IIAs. The substantive standards of bilateral and continental and regional investment treaties in Africa, as well as national investment laws and policies in Africa, are examined. Locknie Hsu starts out with the FDI landscape in 'Asia'. This chapter examines topical issues in investment law and agreements, reflecting a number of themes developed in other chapters, while providing an Asian context. Given the increasing number of treaties and national legislative and judicial actions in Asia which have an impact on international investment law, the region provides rich research material. Examples of regional developments include state actions taken to review, renegotiate or terminate investment treaties, and the growing number of investment disputes involving either an Asian state, an Asian investor, or both. Investment arbitration-related decisions are emerging in Asian courts and these also present important subject matter for analysis, both procedurally as well as substantively. Hsu identifies one emerging research field in the geographical and legal shifts in ISDS as in recent years Asian countries have had ISDS cases brought against them for the first time. While highlighting many piecemeal reforms and developments in Asia, Hsu sees a potential for a future multilateral system in the Belt and Road Initiative, for example. The investment policy in 'Australia and New Zealand' is covered by the chapter by Andrew D Mitchell. Mitchell's review of key substantive protection standards in investment agreements of both states is complemented by many aspects of actuality such as the Philip Morris v Australia arbitration, the conclusion of the Trans-Pacific Partnership (TPP) and the 2016 amendments of the SingaporeAustralia FTA. The chapter outlines core aspects of Australia and New Zealand's IIAs, taking account of the traditional approaches in bilateral investment agreements as well as the more modern approaches in investment chapters of preferential trade agreements. In doing so, the chapter identifies patterns and developments over time and assesses the extent to which the negotiators of both countries have drafted these treaties so as to 
protect their governments' regulatory sovereignty with respect to matters such as public health and other non-trade/investment policy objectives.

Whereas the contribution by Angelos Dimopoulos covers the 'European Union', 'Central and Eastern Europe' is dealt with in a separate chapter by Lénárd Sándor. The reason for this thematic split is twofold. On the one hand the evolution of EU investment policy and its contribution to FDI regulation in the past eight years has been marked by a number of developments, such as the Lisbon Treaty (2009), the negotiation of the Comprehensive Economic and Trade Agreement between Canada and the EU (signed in 2016) and the Transatlantic Trade and Investment Partnership (ongoing), the ruling of the European Court of Justice with respect to the EU-Singapore FTA in May 2017 as well as the EU's reform proposal for a multilateral investment court and the decision of the European Court of Justice in the dispute Slovak Republic $v$ Achmea B.V., to name just a few. These and other aspects offer much room for research and analysis. On the other hand, this means that national views on the ongoing EU reform agenda could not have been represented without a separate chapter. Therefore, the chapter by Angelos Dimopoulos explores the emergence of the EU as a global actor in the field of international investment law and policy. It examines first the legal framework concerning the assumption of powers in the field of foreign investment by the EU. Secondly, it looks into the accommodation of the EU within the existing regime of international investment law. The chapter places particular emphasis on the EU mechanism providing for transitional arrangements for Member State BITs and the EU mechanism on financial responsibility. Finally, it explores the content of EU investment agreements, identifying the key contributions that the EU has developed in this field and its importance as a ground-breaking normative actor. In light of the above, the conclusion is drawn that although the EU's record has not been quantitatively impressive, it is qualitatively substantial, paving the path for a new legal framework on FDI regulation. Additionally, Lénárd Sándor sheds light on those European countries which were not part of the establishment and 'treatification' of international investment law. The high number of ISDS cases against central and eastern European countries plays a major role in his analysis. Sándor analyses the precise context in which central and eastern European countries joined the international investment regime, as well as the basic types of IIAs and their typical provisions in the past quarter century. Moreover, the chapter focuses on the number, nature and experiences of the relevant ISDS cases as well as the dilemma of 'intra-EU BITs' posed by the growing network of BITs between European countries amidst the eastward enlargement of the EU.

Katia Fach Gómez provides interesting insights into investment policy and reform debates in 'Latin America'. The chapter focuses on current legislative policies on investment in Latin American countries, and the main characteristics and legal consequences of the investment arbitration claims with which these states have been confronted to date. Most notably, Fach Gómez reflects on the various initiatives against the traditional ISDS system in Latin America as well as alternatives to the current ISDS system, such as the Brazilian Cooperation and Facilitation Investment Agreements, the planned Union of South American Nations Centre for the Settlement of Investment Disputes, the Ecuadorian Commission for a Comprehensive Audit of 
Investment Protection Treaties and of the International Arbitration System on Investments, and the Southern Observatory on Investment and Transnational Corporations. Finally in this part, the contribution by Kendra Magraw on 'North America' examines more than 20 years of the North American Free Trade Agreement (NAFTA). The chapter focuses on the United States of America, Canada and Mexico in depth, although it may also briefly touch on the international investment regime policies of other countries in North America. The chapter explains the convergence of the countries' FDI objectives and discusses lessons learned from NAFTA and developments that followed. Moreover, the current status of the countries' investment regimes and current challenges facing the North American countries are discussed. Magraw argues that North American countries currently face a renewed challenge in the coherence of their FDI policies in the form of NAFTA renegotiations - possibly showing the somewhat divergent paths of the United States of America, Canada and Mexico.

\section{CHALLENGES AND CONTENTIOUS ISSUES}

Chapters in this final part of the Research Handbook deal with cross-cutting issues and challenges between FDI and other fields of international and domestic law and politics. First, Stefanie Schacherer and Rhea Tamara Hoffmann explore the relationship between 'International investment law and sustainable development'. The chapter seeks to highlight the aspects of international investment law that are relevant within the context of achieving sustainable development such as key substantive investment norms. The chapter examines investment promotion as well as investment facilitation, which may be conditioned on sustainable development objectives or may be more accurate to serve the goal of sustainable development. Another section of the chapter is dedicated to ISDS and sustainable development, looking at - on the one hand - investment treaty cases with sustainable development implications as well as the design of ISDS on the other hand. Furthermore, the role of impact assessments and specific chapters on sustainable development in free trade agreements are highlighted. Finally, the chapter concludes with pointing out some future research questions with respect to sustainable development and international investment law. Secondly, the 'Protection of the environment and international investment law' is covered by Sabrina Robert-Cuendet. The chapter looks at the clash between IIAs and the protection of the environment. International investment law has revealed all its potentialities - and its negative impacts - through many investment arbitrations related to host state's environmental regulations. The chapter details the terms of the tension between investment and environment and drafts some propositions to reconcile the two. Therefore, it analyses the main types of environmental provisions in IIAs and proposes to go further in the 'greenisation' of IIAs, with propositions turned on the investor's responsibility. Finally, whether ISDS mechanisms are suitable to settle environmental-related disputes is examined.

Thirdly, Eric De Brabandere examines the interaction between 'Human rights and international investment law'. Besides the question whether there is a conflict between human rights and international investment law as well as other aspects, the chapter 
highlights possible investor obligations in FDI regulations which raise complex issues. Human rights issues interact in various ways with investment law. Therefore, it addresses the limited scope of the jurisdiction of investment tribunals, the effect of the insertion in investment treaties of clauses concerning the obligations of foreign investors, and the effect of 'legality' requirements in investment treaties. Furthermore, the 'conflict' between human rights obligations and investment treaty obligations and the applicable rules on treaty conflict are examined. Finally, in the last contribution Christina Binder and Philipp Janig deal with 'Investment agreements and financial crises' as a still contentious issue for further research in the field. Arbitral proceedings have highlighted the complex and sometimes problematic tension between necessary state measures to address crisis situations and obligations entered into vis-à-vis foreign investors mainly in bilateral investment agreements. After an introduction into the types of pertinent state measures typically taken during financial crises, this chapter describes possible impacts on the rights of investors, the applicable regulatory framework and available legal defences on the part of the state. The contribution focuses specifically on Argentina, Greece and Cyprus. In a final section, this contribution briefly discusses recommendations aimed at addressing the shortcomings within the current legal framework and practice. 